JURNAL RESPIRASI

$J R$

Vol. 1 No. 3 September 2015

\title{
Sequelae Tuberkulosis dengan Hemoptisis Rekurens
}

\author{
Desilia Atikawati, Isnin Anang Marhana \\ Departemen Pulmonologi dan Ilmu Kedokteran Respirasi, Fakultas Kedokteran Universitas Airlangga/RSUD Dr. Soetomo
}

\begin{abstract}
Background: Various sequelae and complications can occur in treated or untreated tuberculosis (TB). One of complications in the lungs is hemoptysis, due to alterations of pulmonary vascular structure. Hemoptysis as TB sequelae can happen recurrently and massively. Case: We present the case of 31 year old man with recurrent hemoptysis since 1 year before admitted to hospital. Patient had a history of receiving antituberculosis drugs (ATD) before. Chest xray showed pleural thickening and opacity in right hemithorax with signs of loss of volume. Bronchoscopy showed active bleeding in lateral segment of right lung middle lobe. Chest CT showed destroyed right lung. Hemoptysis still existed despite the given conventional therapy, thus patient underwent pulmonary arteriography. The result showed extensive vascular abnormality in the right lung with arteriovenous fistula on right bronchial artery and aneurysmatic branch of superior bronchial and inner intercostal arteries. During the procedure, there was no active bleeding, so bronchial artery embolization was adjourned. Patient then experienced recurrent and massive hemoptysis, thus right pneumonectomy was done. During the surgery, there was uncontrolled active bleeding that caused the patient's death. Conclusion: This case illustrates recurrent hemoptysis as one of severe TB sequelae. In extensive pulmonary vascular abnormality, pneumonectomy can cause uncontrolled active bleeding. Bronchial artery embolization can be used as an alternative to treat patients with recurrent homptysis..
\end{abstract}

Key words: sequelae of TB, recurrent hemoptysis

Correspondence: Desilia Atikawati, Departemen Pulmonologi dan Ilmu Kedokteran Respirasi, Fakultas Kedokteran Universitas Airlangga/RSUD Dr. Soetomo. Jl. Mayjen. Prof. Dr. Moestopo 6-8 Surabaya 60286. E-mail: desiliaatikawati@gmail.com

\section{PENDAHULUAN}

Tuberkulosis (TB) adalah penyakit yang disebabkan oleh infeksi Mycobacterium tuberculosis complex dan terutama mengenai parenkim paru. Perkiraan kasus TB secara global pada tahun 2009 yaitu insidensi kasus 9,4 juta, prevalensi kasus 14 juta, kasus meninggal dengan HIV negatif 1,3 juta, dan kasus meninggal dengan HIV positif 0,38 juta. ${ }^{1}$ Pada tahun 2011, Indonesia merupakan negara dengan pasien TB terbanyak ke-4 di dunia setelah India, Cina, dan Afrika Selatan. Diperkirakan jumlah pasien TB di Indonesia sekitar 5,7\% dari total jumlah pasien TB dunia, dengan 450.000 kasus baru dan 65.000 kematian setiap tahunnya. ${ }^{2}$

Berbagai macam sequelae dan komplikasi dapat terjadi pada TB, baik yang diterapi maupun tidak. Komplikasi yang terjadi pada paru dapat dikategorikan sebagai lesi parenkim, saluran napas, vaskular, pleura, dan komplikasi sistemik. Lesi vaskular yang dapat terjadi adalah hemoptisis. Hemoptisis adalah ekspektorasi darah yang berasal dari paru atau saluran trakeobronkial. Hemoptisis terjadi akibat perubahan struktur vaskular pada paru. Fritz Valdemar Rasmussen (1886) menyatakan adanya dilatasi aneurismatik dari pembuluh darah paru di dinding kavitas TB sebagai penyebab hemoptisis. Calmette (1923) menyatakan adanya cabang a.pulmonalis pada dinding kavitas yang disebut "aneurysms of Rasmussen". ${ }^{3}$

\section{KASUS}

Seorang laki laki berusia 34 tahun, pekerjaan swasta, masuk rumah sakit (MRS) di Ruang Palem I dengan keluhan batuk darah. Jumlah darah yang keluar adalah sekitar 200 cc. Nafsu makan menurun, berat badan menurun, tetapi tidak ada keluhan keringat malam atau panas badan. Di ruangan, pasien diterapi dengan posisi trendelenberg, $\mathrm{O} 2$ nasal 3 lpm, $\mathrm{NaCl}$ 0,9\% 1 flash/hari, 
Aminofluid 1 flash/hari, dan Codein 310 mg PO. Pasien kami rencanakan untuk dilakukan pemeriksaan sputum BTA, kultur dan sensitivitas M.tuberculosis, dan fiberoptic bronchoscopy (FOB). Hasil foto toraks (gambar 1) saat masuk menunjukkan schwarte kanan atas disertai efusi pleura kanan yang mengalami organisasi. Berdasarkan hasil sputum BTA menunjukkan negatif. Setelah 3 hari bebas batuk darah, pasien dilakukan pemeriksaan spirometri (untuk persiapan FOB) dengan hasil restriksi berat dan obstruksi berat (FEV1/FVC 64\%, FEV1 17\%, FVC 25\%), namun hasil spirometri tidak acceptable dan reproducible karena pasien terus batuk dalam posisi duduk. Oleh karena itu, dilakukan pemeriksaan analisis gas darah tanpa oksigen, tetapi hasilnya tidak memenuhi syarat sehingga belum dapat dilakukan FOB. Selama dirawat, penderita sering batuk darah sebanyak 5-200 cc yang diselingi dengan beberapa hari periode bebas batuk darah. setelah enam hari MRS dengan tenggang waktu selama satu minggu, penderita mengalami batuk darah sebanyak $\pm 50-100$ cc/hari, sehingga kami konsulkan ke departemen bedah torakokardiovaskular (BTKV) pada keesokan harinya dengan hasil jawaban konsul adalah tidak didapatkan tandatanda hemoptisis masif (emergency), sehingga belum perlu dilakukan tindakan operatif di bidang bedah TKV, dan sejak itu penderita rawat bersama dengan BTKV.

Delapan belas hari MRS penderita dilakukan pemeriksaan FOB dengan hasil keradangan paru kronis dan didapatkannya perdarahan aktif di segmen lateral lobus medius paru kanan. Telah dilakukan juga pemberian adrenalin saat FOB untuk menghentikan perdarahan. Pada cairan bronchoalveolar lavage (BAL) tidak ditemukan BTA. CT scan toraks (gambar 2) dilakukan keesokan hari setelah pemeriksaan FOB dengan kesan TB paru dengan destroyed lung kanan, paraseptal emfisema di segmen apikoposterior lobus superior paru kiri, dan efusi pleura kanan yang terorganisasi. Setelah selama 3 hari bebas batuk, Tiga minggu MRS penderita batuk darah sebanyak 200 cc. Dengan kejadian kondisi penderita yang batuk darah sebanyak $200 \mathrm{cc}$ maka dan dilakukan chest conference yang terjadwal dua hari keesokan harinya dengan dihadiri oleh 5 departemen (paru, BTKV, radiologi, rehabilitasi medik, dan anestesi) dengan kesimpulan; pada penderita dilakukan pemeriksaan GeneXpert (untuk memastikan status TB), terapi OAT (menunggu hasil GeneXpert), konsultasi kepada bagian radiologi intervensi untuk pertimbangan dilakukannya arteriografi dan embolisasi a.bronkialis, serta bila batuk darah terus berlangsung akan dilakukan pneumonektomi.

Satu bulan lebih dua hari MRS penderita dilakukan pemeriksaan arteriografi. Saat itu penderita telah bebas batuk darah selama tiga hari. Rencana tindakan yang akan dilakukan yaitu pada saat arteriografi akan diidentifikasi letak sumber perdarahan, kemudian akan dilakukan embolisasi atau clipping pada pembuluh darah tersebut. Pada arteriografi ditemukan kelainan vaskular yang luas pada paru kanan. Didapatkan AV fistel a.bronkialis kanan disertai gambaran aneurismatik dari cabang a.bronkialis superior dan intercostalis interna. Saat ini tidak tampak gambaran ekstravasasi kontras. Embolisasi arteri tidak dapat dilakukan. Oleh karena kelainan yang luas, embolisasi atau clipping arteri tidak dapat dilakukan. Advis dari bagian radiologi intervensi adalah observasi penderita dan bila batuk darah kembali maka prosedur dapat diulang lagi, setelah dilakukan pemeriksaan arteriografi dua hari kemudian terdapat hasil GeneXpert yang menunjukkan M.tuberculosis negatif. Dari rangkaian pemeriksaan penunjang untuk diagnosis TB yang telah dilakukan, akhirnya disimpulkan bahwa penderita tidak menderita TB aktif, melainkan sequelae TB dan tidak diberi OAT. Setelah itu penderita tidak mengalami batuk darah selama empat hari lagi.

Pada Satu bulan lebih delapan hari, penderita tibatiba mengalami batuk darah masif (250 cc di setiap batuk, jumlah \pm 600-700 cc/hari), sehingga oleh BTKV direncanakan untuk pneumonektomi cito. Selama Satu bulan setengah MRS penderita dilakukan tindakan operatif. Penderita diposisikan lateral dekubitus kiri lalu dilakukan insisi torakotomi posterolateral. Pada eksplorasi didapatkan perlekatan hebat antara pleura dengan dinding dada dan schwarte setebal $3 \mathrm{~cm}$. Hilus diidentifikasi dan didapatkan perdarahan, sehingga dilakukan jahitan hemostasis, selanjutnya dilakukan pneumonektomi, tetapi perdarahan aktif belum terkontrol. Hemodinamika penderita tidak stabil dengan tekanan darah 60/palpasi dan nadi 50 '/menit. Dilakukan resusitasi cairan secara agresif, transfusi PRC dan FFP, serta pemberian vascon (400 mcg/menit), adrenalin (400 mcg/menit), dan dopamin (15 mcg/menit). Oleh karena penderita tetap tidak stabil, dilakukan pemasangan tampon dan drain di rongga toraks lalu kulit dijahit situasional dan penderita dipindahkan ke ICU. Selama di ICU, penderita terus mendapatkan vasopressor dengan dosis sama, transfusi, serta resusitasi cairan untuk menstabilkan kondisinya. Produksi darah pada drain masih terus keluar (hingga $600 \mathrm{cc}$ dalam 2 jam). Penderita akhirnya meninggal di hari yang sama dengan sebab kematian perdarahan aktif.

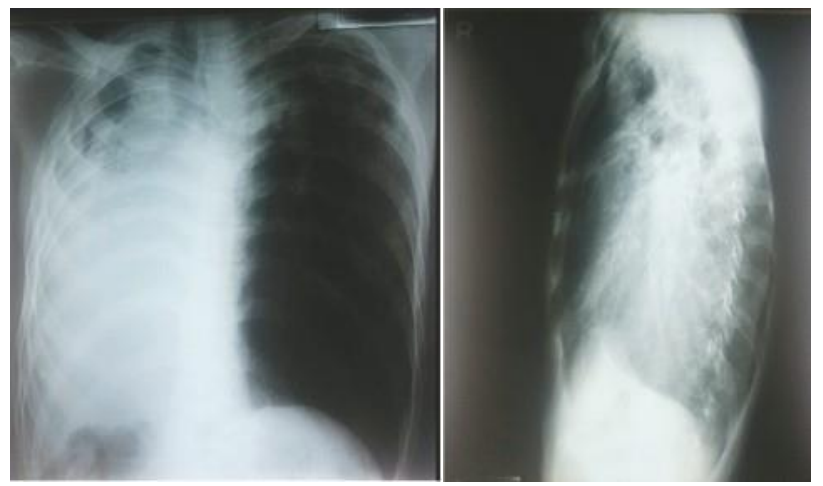

Gambar 1. Foto Thorak 

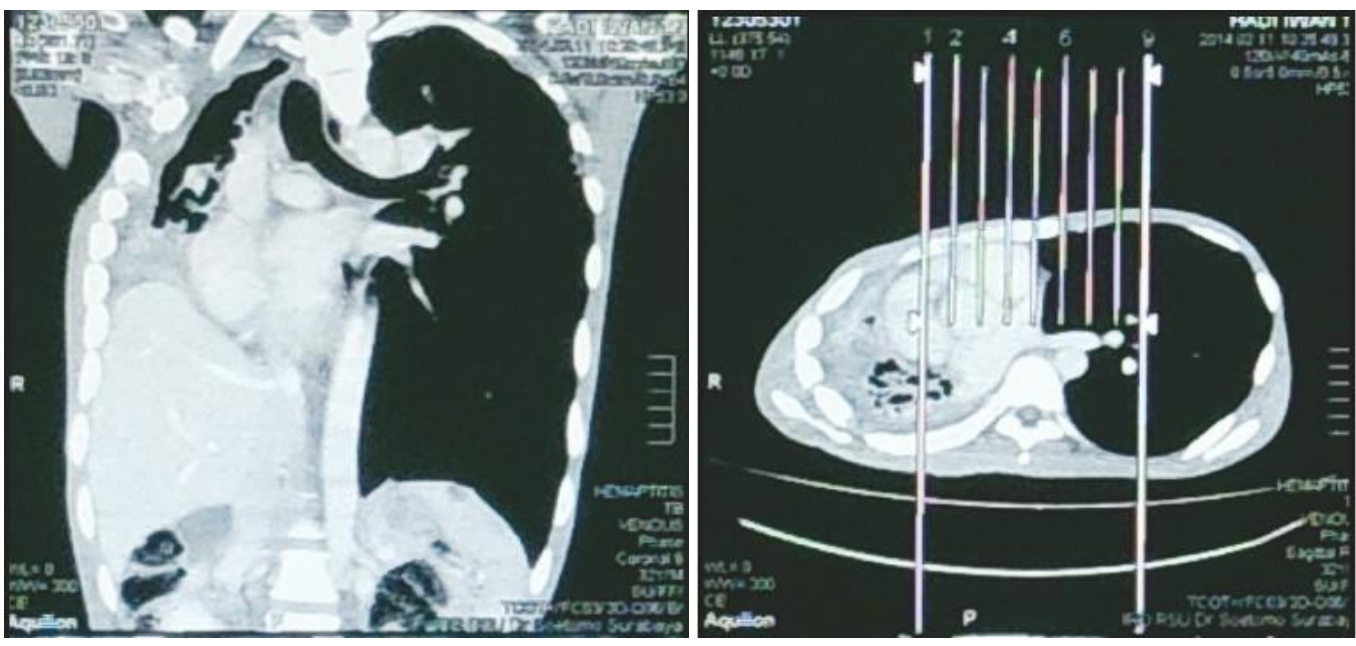

Gambar 2. CT Scan Thorak

\section{DISKUSI}

Sequelae TB adalah kondisi yang disebabkan oleh berbagai perubahan patologis dari anatomi paru pada proses penyembuhan TB paru yang membutuhkan penatalaksanaan tertentu untuk mengatasi gejala klinis yang terjadi. ${ }^{4}$ Beratnya penyakit TB ditentukan oleh interaksi antara respons pejamu dan virulensi organisme. Pertahanan tubuh yang utama dalam melawan basil TB ada cell-mediated immunity yang diperankan oleh makrofag dan sel limfosit T. Apabila faktor imunitas pejamu lebih kuat dari virulensi bakteri, maka akan terjadi penyembuhan secara bertahap dengan pembentukan jaringan ikat pada parenkim paru. Jika virulensi bakteri lebih kuat dari Imunitas pejamu, penyakit dapat berkembang secara lokal maupun di bagian paru lainnya atau organ di luar paru setelah terjadi penyebaran bakteri lewat saluran napas, pembuluh limfatik, atau pembuluh darah. Pada keadaan ini, penyakit cenderung bersifat lebih berat. ${ }^{5}$ Komplikasi yang terjadi akibat proses penyembuhan TB sangat bervariasi. Sequelae TB dapat dikategorikan sebagai berikut: (a) lesi parenkim, (b) lesi pada saluran napas, (c) lesi vaskular,

(d) lesi pleura, dan (e) komplikasi umum (cor-pulmonale, amiloidosis sekunder, gagal napas kronis). Hemoptisis merupakan salah satu sequelae TB yang termasuk ke dalam lesi vaskular. ${ }^{3}$

Hemoptisis adalah batuk darah yang berasal dari paru atau saluran bronkus, disebabkan oleh perdarahan dari arteri bronkialis atau pulmonalis. Hemoptisis dikategorikan non-masif atau masif berdasarkan volume darah yang hilang. Hemoptisis termasuk non-masif jika darah yang dibatukkan < $200 \mathrm{ml} /$ hari. $^{6}$ Adapula pembagian hemoptisis berdasarkan jumlahnya adalah sebagai berikut: ringan: < 100 cc dalam 24 jam; sedang: 100-600 cc dalam 24 jam; masif: > $600 \mathrm{cc}$ dalam 24 jam atau > $30 \mathrm{cc} / \mathrm{jam}^{7}$ Walaupun tidak ada definisi pasti mengenai volume darah yang termasuk hemoptisis masif, beberapa penelitian menyebutkan volume darah mulai dari 100 cc hingga $\geq 1000$ cc/hari. Oleh karena anatomical dead space dari saluran napas utama adalah 100-200 cc, definisi hemoptisis masif yang lebih relevan adalah volume yang dapat mengancam nyawa akibat obstruksi saluran napas atau kehilangan darah. ${ }^{8}$ Pada paru terdapat dua sistem vaskular, yaitu: (1) Arteri pulmonalis, yang memiliki peran $99 \%$ dari total suplai darah arteri ke paru dan berfungsi dalam pertukaran gas; (2) Arteri bronkialis, yang bertanggung jawab dalam menyediakan nutrisi untuk struktur pendukung saluran napas, tetapi secara normal tidak nerperan dalam pertukaran gas. ${ }^{9}$ Pada hemoptisis, perdarahan dapat berasal dari sirkulasi arteri sistemik (sistem dengan tekanan tinggi dari arteri bronkialis) dan sirkulasi arteri paru (sistem dengan tekanan rendah dan berasal dari arteri pulmonalis). Secara histologis, kedua sistem dihubungkan oleh anastomosis antara kapiler sistemik dan pulmonalis. Kondisi-kondisi yang menyebabkan penurunan sirkulasi arteri pulmonalis dan iskemia (contoh: tromboemboli kronis), sirkulasi bronkialis memberikan respons dengan proliferasi dan hipertrofi vaskular fokal lewat saluran anastomosis untuk menggantikan sirkulasi arteri pulmonalis. Penyakit neoplasma dan inflamasi kronis (bronkiektasis, infeksi kronis seperti TB) akan merangsang neovaskularisasi dan meningkatkan sirkulasi sistemik yang dimediasi oleh angiogenic growth factors. Pembuluh darah sistemik yang baru dan hipertrofi ini biasanya sangat rapuh dan terpapar oleh tekanan sistemik, sehingga cenderung ruptur pada bagian distalnya ke dalam lumen bronkus atau alveoli dan menyebabkan hemoptisis. ${ }^{9}$

Pada sebagian besar kasus (90\%), hemoptisis, terutama hemoptisis masif, berasal dari sirkulasi arteri sistemik. ${ }^{7}$ Pada 10\% kasus, hemoptisis disebabkan oleh sistem arteri pulmonalis. Hemoptisis rekurens dan hemoptisis masif seringkali terjadi pada kelainan paru kronis, seperti tuberkulosis, bronkiektasis dan abses paru.10 Pada tuberkulosis, hemoptisis dapat terjadi karena beberapa 
hal, antara lain; (a) Kelainan paru aktif dengan atau tanpa kavitas dapat menyebabkan perdarahan baik dengan jumlah sedikit atau banyak. Pada sebagian besar penderita ini ditemukan bakteri tahan asam (BTA) pada sputumnya; (b) Kelainan TB aktif dapat menyebabkan ruptur spontan dari aneurisma rasmussen. ${ }^{11}$ Aneurisma rasmussen adalah suatu komplikasi TB paru yang merupakan suatu aneurisma arteri pulmonalis di sekitar atau dalam kavitas TB. Terbentuknya aneurisma rasmussen disebabkan oleh kelemahan progresif dinding arteri pulmonalis pada kavitas TB yang terjadi seiring pergantian lapisan media dan adventitia dinding vaskular oleh jaringan granulasi. Lapisan tersebut secara perlahan akan digantikan oleh fibrin. Hal ini menyebabkan penipisan dinding arteri, pembentukan pseudoaneurisma, dan perdarahan akibat ruptur. ${ }^{12}$ Aneurisma juga dapat berasal dari arteri bronkialis; (c) TB yang tidak aktif dapat menyebabkan perdarahan akibat bronkiektasis residual, erosi bronkolit lewat pembuluh darah dan ke saluran napas, atau dengan meninggalkan kavitas yang selanjutnya menjadi tempat terjadinya mycetoma.11 Ruptur aneurisma juga merupakan penyebab hemoptisis pada TB yang tidak aktif; (d) Erosi pembuluh darah akibat lesi yang mengalami kalsifikasi; ${ }^{3}$ (e) Scar carcinoma (hal jarang) yang terbentuk di area pneumonitis TB lama. Selain aneurisma Rasmussen, sumber perdarahan dari setiap penyebab hemoptisis di atas biasanya disebabkan oleh sirkulasi arteri bronkialis. ${ }^{11}$

Berbagai pemeriksaan penunjang dapat dilakukan dalam menegakkan diagnosis penyebab hemoptisis, yaitu; (1) Foto toraks. Foto toraks dapat mengidentifikasi lokasi perdarahan pada 46-82\% kasus. Berbagai kelainan foto toraks juga dapat menunjukkan diagnosis spesifik. ${ }^{13}$ Gambaran radiologi pada TB aktif adalah bayangan berawan/nodular di segmen apikal dan posterior lobus atas paru dan segmen superior lobus bawah, kavitas (terutama lebih dari satu, dikelilingi oleh bayangan opak berawan atau nodular), bayangan bercak milier, dan efusi pleura uniateral (umumnya) atau bilateral (jarang). Gambaran radiologi yang dicurigai sebagai lesi tidak aktif antara lain fibrosis, kalsifikasi, dan schwarte atau penebalan pleura. Pada TB juga dapat ditemukan gambaran destroyed lung, yaitu gambaran yang menunjukkan kerusakan jaringan paru berat, dapat terdiri dari atelektasis, ektasis/multikavitas, dan fibrosis, ${ }^{1}$ (2) Fiberoptic bronchoscopy (FOB). FOB dapat membantu visualisasi perdarahan dan mengkonfirmasi diagnosis hemoptisis, serta mencari lokasi sumber perdarahan. Nilai operasional FOB dalam mengidentifikasi sumber perdarahan adalah 34-93\% ketika dilakukan pada awal hemoptisis, dan menurun hingga 11-50\% jika dilakukan terlambat. Nilai operasional juga menurun pada hemoptisis masif. FOB juga dapat membantu identifikasi penyebab perdarahan, mengambil spesimen mikrobiologi, dan biopsi jaringan. FOB dan CT-scan dapat menjadi prosedur yang saling melengkapi; ${ }^{13}$ (3) Multidetectory row computed tomography (MDCT) angiography. Saat ini MDCT angiography memegang peranan penting dalam penatalaksanaan hemoptisis. MDCT angiography dapat menentukan lokasi perdarahan pada 70-80\% kasus, mendiagnosis penyebab hemoptisis dengan sensitivitas yang tinggi, dan memberikan gambaran detil dari struktur vaskular toraks (sistem arteri pulmonalis dan arteri bronkialis) serta mekanisme yang memungkinkan menjadi penyebab hemoptisis. ${ }^{13}$ MDCT angiography memberikan evaluasi yang detil dari mediastinum dan parenkim paru. Struktur vaskular toraks tersebut akan sangat bermanfaat dalam merencanakan embolisasi atau operasi. ${ }^{9}$

Arteri bronkialis berasal dari descending thoracic aorta pada ketinggian corpus vertebra T5-T6. Pada MDCT angiography, arteri bronkialis terlihat di mediastinum posterior sebagai titik atau garis (hampir tidak terlihat jika tidak hipertrofi. Pola percabangan arteri bronkialis sangat bervariasi. Diameter arteri bronkialis $>2 \mathrm{~mm}$ dianggap sebagai keadaan patologis dan merupakan indikasi untuk dilakukan embolisasi. Walaupun begitu, tidak terdapat korelasi yang signifikan antara ukuran arteri dan risiko perdarahan. ${ }^{9}$ Selain arteri bronkialis, sistem arteri pulmonalis juga perlu dievaluasi. Tujuannya adalah untuk mengidentifikasi aneurisma atau pseudoaneurisma, yang terlihat pada MDCT angiography sebagai dilatasi sakular atau fusiform terisi kontras dari arteri pulmonalis. ${ }^{9}$ Pendekatan pada penatalaksanaan hemoptisis masif dimulai dari resusitasi dan proteksi jalan napas. Langkah kedua adalah melokalisasi sumber dan penyebab perdarahan. Langkah terakhir adalah terapi definitif dan spesifik untuk mencegah perdarahan berulang. ${ }^{8}$ Pada tahap awal, perlu dilakukan edukasi pada penderita untuk tetap tenang dan jangan takut membatukkan darahnya. Patensi jalan napas hari dipertahankan. Resusitasi cairan/darah dilakukan bila hemdinamika tidak stabil. Bila perlu dapat diberikan obat hemostatik (asam traneksamat, karbazokrom, vitamin $\mathrm{K}$ ), penekan refleks batuk (codein) dan obat sedasi. ${ }^{14}$ Bila keadaan umum dan refleks penderita baik, maka penderita dapat diminta untuk duduk lalu pimpin untuk batuk. Beri tahu penderita untuk tidak takut batuk. Bila keadaan umum lemah/sakit berat dan refleks batuk tidak adekuat, maka penderita diminta untuk berada dalam posisi trendelenberg dan miring ke sisi yang sakit. Jika perlu pasang ETT. Bila gagal napas, maka lakukan pemasangan ventilasi mekanik. $^{15}$

FOB memiliki peran penting pada hemoptisis, yaitu untuk mengontrol perdarahan serta melakukan suction darah dan membersihkan bekuan darah yang mengobstruksi saluran napas. Bekuan darah yang terlokalisasi seharusnya tidak diambil karena justru dapat meyebabkan hemoptisis yang banyak dan mengancam. Beberapa teknik yang dapat dilakukan pada saat FOB antara lain lavage dengan $\mathrm{NaCl}$ dingin sebanyak $500 \mathrm{cc}$. Jika perdarahan masih tidak terkontrol, vasokonstriktor topikal seperti adrenalin (1:20.000) dan tamponade mekanis (fogarty cathether) dapat digunakan. Rigid bronchoscopy mampu memfasilitasi suction lebih efisien untuk mempertahankan jalan napas, tetapi akibat ketidakmampuannya dalam mengidentifikasi lesi perifer, teknik ini mulai tidak dipakai. ${ }^{13}$ Fotokoagulasi laser (Nd-YAG) pada lesi endobronkial juga dapat dilakukan untuk menghentikan perdarahan. ${ }^{15}$ 
Bronchial artery embolization (BAE) merupakan prosedur non-bedah dalam terapi hemoptisis. BAE dapat bersifat life-saving, menunda atau menggantikan tindakan bedah, dan pada beberapa kasus menjadi pilihan terapi. Indikasi BAE antara lain kegagalan terapi konservatif, hemoptisis masif, hemoptisis rekurens, dan risiko tinggi operasi. BAE juga dapat dilakukan untuk mengontrol perdarahan sementara sebelum operasi. ${ }^{16}$ Dahulu, operasi adalah terapi definitif, namun intervensi bedah memiliki mortalitas $\pm 18 \%$ bila dilakukan elektif dan meningkat hingga $40 \%$ bila dilakukan dalam keadaan darurat. Tindakan konservatif seperti observasi dan obat-obatan juga meningkatkan angka mortalitas hingga 50\%. BAE saat ini telah dianggap sebagai lini pertama dalam terapi hemoptisis. Sebagian kecil kasus hemoptisis disebabkan oleh sistem arteri pulmonalis. Pada kasus ini, BAE mungkin tidak akan memberikan resolusi klinis yang adekuat dan membutuhkan beberapa intervensi. ${ }^{17}$ Tingkat kesuksesan BAE post embolisasi mencapai 73-99\%. Walaupun begitu, rekurensi masih dapat terjadi pada 10-55\% dalam 46 bulan follow up. Proses yang berperan dalam terjadinya rekurensi adalah rekanalisasi (terutama bila agen yang digunakan bersifat absorable), angiogenesis dan keterlibatan vaskular yang lebih lanjut. TB paru, aspergillus, dan kanker paru merupakan faktor risiko terjadinya hemoptisis rekurens. Reembolisasi dapat dilakukan pada hemoptisis rekurens, namun tindakan bedah tetap menjadi terapi definitif pada kasus hemoptisis yang terus terjadi walau telah dilakukan embolisasi multipel dan terapi obat-obatan maksimal. ${ }^{17}$ Komplikasi dari prosedur BAE yaitu nyeri dada (komplikasi tersering, yaitu 24-91\%, dan dapat hilang sendidari prosedur BAE yaitu nyeri dada (komplikasi tersering, yaitu 24-91\%, dan dapat hilang sendiri), transient dysphagia (18\%, dapat hilang sendiri), ransverse myelitis akibat iskemia spinal cord (komplikasi paling serius dari BAE), cortical blindness, nyeri daerah orbital atau temporal ipsilateral, stenosis bronkus, nekrosis, dan bronchoesophageal fistula. ${ }^{17}$ Penelitian lain menunjukkan beberpa komplikasi yang juga dapat terjadi akibat BAE, yaitu paraplegia, transient paraplegia, transient Brown-Sequard syndrome, dan stroke. Kontraindikasi dilakukannya BAE sama dengan kontraindikasi angiografi pada umumnya yaitu koagulopati yang tidak terkoreksi, gagal ginjal, dan alergi kontras. ${ }^{18}$

Tindakan bedah dapat menjadi pilihan dalam penatalaksanaan hemoptisis, namun hampir $50 \%$ dari penderita hemoptisis tidak dapat dilakukan operasi akibat fungsi jantung paru yang tidak memadai. Selain itu, angka mortalitas akibat operasi, terutama yang bersifat darurat, mencapai 23-50\%. Tindakan bedah seharusnya hanya dikerjakan pada penderita dalam keadaan darurat dimana fasilitas BAE tidak ada, secara teknik tidak mungkin dilakukan BAE (adanya arteri spinal), serta perdarahan aktif persisten setelah BAE. Reseksi paru (segmentektomi, lobektomi, pneumonektomi) dipertimbangkan untuk lesi fokal, terutama yang memiliki kecenderungan untuk mengalami perdarahan berulang (seperti mycetoma). Keuntungan harus dibandingkan dengan risiko komplikasi operasi. Komplikasi post-operasi antara lain perdarahan, empyema, infeksi paru, infeksi luka operasi, gagal napas, dan bronchopleural fistula. ${ }^{13}$

\section{KESIMPULAN}

Telah dilaporkan kasus seorang penderita berusia 31 tahun, datang ke RSUD Dr. Soetomo dengan keluhan batuk darah. Pada foto toraks tampak gambaran TB dengan schwarte. Pada CT scan toraks tampak gambaran destroyed lung kanan, tetapi MDCT angiography tidak dilakukan. Hasil pewarnaan sputum, BAL, GeneXpert, dan kultur tidak menunjukkan TB aktif. Telah dilakukan terapi awal serta FOB, namun pada perjalanannya batuk darah terus berulang. Penderita direncanakan untuk dilakukan BAE sebagai terapi definitif, namun sedang tidak terjadi perdarahan aktif dan risiko komplikasi yang mungkin terjadi dianggap lebih besar dibandingkan keuntungannya, sehingga diputuskan untuk ditunda. Saat penderita mengalami hemoptisis masif, reseksi paru dilakukan. Pneumonektomi merupakan pilihan tipe reseksi paru oleh karena perlekatan yang luas dan tebal dalam rongga toraks. Pada akhirnya, penderita meninggal akibat perdarahan hebat yang terjadi saat operasi.

\section{DAFTAR PUSTAKA}

1. Perhimpunan Dokter Paru Indonesia. (2011). Tuberkulosis: pedoman diagnosis dan penatalaksanaan di Indonesia. Jakarta: Perhimpunan Dokter Paru Indonesia, p. 2, 16-24.

2. Kementrian Kesehatan Republik Indonesia. (2013). Pedoman nasional pelayanan kedokteran tatalaksana tuberkulosis. Jakarta: Kementrian Kesehatan RI, p. 8, 68-70.

3. Devi G. (2014). Complication of pulmonary tuberculosis. M.S Ramaiah Medical College India. http://www.iconceptpress.com/ books/040-11/ tuberculosis-a comprehensive-clinical-reference/.

4. Yoneda R. (1990). Tuberculosis sequelae. Tokyo national chest hospital, 65: 827-9.

5 Kim HY, Song KS, Goo JM, Lee JS, Lee KS, Lim TH. (2001). Thoracic sequelae and complications of tuberculosis. RSNA, 21: 839-60.

6. Bidwell JL, Pachner RW. (2005). Hemoptysis: diagnosis and management. American Family Physician, 72: 1253-60.

7. Lundgren FL, Costa AM, Figueiredo LC, Borba PC. (2010). Hemoptysis in a referral hospital for pulmonology. Jornal Brasileiro de Pneumologia,36: 320-4

8. Lordan JL, Gascoigne A, Corris PA. (2003). The pulmonary physician in critical care: assessment and management of massive hemoptysis. BMJ Thorax, 58: 814-9.

9. Spinu C, Gonzalez EC, Andreu M, Gallardo X, Duaso MM, Bustelo JC. (2013). Life threatening hemoptysis: role of MDCT angiography. European Society of Radiology. p. 1-25.

10. Agmy GM, Wafy SM, Mohamed SA, Gad YA, Mustafa H, El-Aziz AE. (2013). Bronchial and nonbronchial systemic artery embolization in management of hemoptysis: experience with 348 patients. ISRN Vascular Medicine, 2013: 1-5.

11. Ingbar DH. (2005). Causes and management of massive hemoptysis in adults. http://critical.med.ualberta.ca/FileArchive/ /media/ criticalcare/Documents/Causesandmanagementofmassivehemoptys is.pdf

12. Shetty A, Badawy A. Rasmussen's aneurysm. http://radiopaedia.org/ articles/ rasmussen-aneurysm.

13. Parrott A, Djibre M, Roques S, Khalil A, Fartoukh M. (2012). Hemoptysis. http://www.antimicrobe.org/new/e52.asp. 
14. Etty Sumiyeti. (2012). Batuk darah (hemoptisis). Pertemuan Ilmiah Respirologi Bekasi. Bekasi, 3 Juni 2012.

15. Boedi Swidarmoko. (2013). Management of difficult airways in massive hemoptysis. PIPKRA. 7-8 Februari 2013.

16. Samara KD, Tsetis D, Antoniou KM, Protopapadakis C, Maltezakis G, Siafakas NM. (2011). Bronchial artery embolization for management of massive cryptogenic hemoptysis: a case series. Journal of Medical Case Report, 58: 1-4.
17. Sopko DR, Smith TP. (2011). Bronchial artery embolization for hemoptysis. Seminar in Interventional Radiology, 28: 42-62.

18. Sidhu M, Wieseler K, Burdick TR, Shaw DW. (2008). Bronchial artery embolization for hemoptysis. Seminar in Interventional Radiology, 25 (3): 310-8. 